castrated woman. It shows that the conversion of progesterone into PG and its excretion may vary with the functional state of the endocrine glands.

9) Only a slight difference was found in the time of appearance of PG in urine according as the progesterone was given by intravenous, intramuscular or oral administration, though no difference was found in the total amount of PG in urine.

10) No difference was remarkable in the amount of PG in urine according as the estrogen treatment was done or not before administration of progesterone to the castrated woman.

11) Administration of ACTH, cortisone acetate, T.B.H. or testostrone propionate to the castrated woman had no influence upon the amount of PG in urine, though the number of eosinophile leucocytes in blood or the amount of 17K.S. in urine was influenced.

\title{
Influence of Thyroid Hormone on the Release of Antidiuretic Hormone from Neurohypophysis.
}

\author{
By
}

Takashi UENO and Michie KUROKAWA

Institute of Physiology, School of Medicine, University of Nagoya.

The effect of the thyroid activity on the antidiuretic potency of blood serum and on the ADH content in neurohypophysis was studied in rats biologically and also by means of Gomori's alum-chromehematoxylin-phloxine staining.

In the thyroidectomized rats, 28 days after the operation, the $\mathrm{ADH}$ content in neurohypophysis and the blood ADS were slightly higher than normal levels.

In rats injected hypodermically with 0.05 or $0.5 \mathrm{ml}$ of Thyradin (corresponded to 10 or $100 \mathrm{mg}$ of desicated thyroid) per $100 \mathrm{~g}$ body weight daily for the periods of 12 or 28 days, ADH content and blood ADS were moderately lower than normal values.

In neither above mentioned cases, any significant cytological change in the posterior pituitary gland and in neurosecretory nuclei of hypothalamus occured. 


\title{
甲状腺ホルモンの脳下垂体後葉 抗利尿木ルモンに及ぼす影響
}

\author{
名古屋大学医学部生理学教室第 1 講座
}

上野喬・黑 川道 江

各種動物の水代謝が用状腺の投与によつて影響をうけるととが知られている1-6). ネズミに thyroxine を 与えると，水分搨取量と尿量が 2 倍になり， $\mathrm{Cl}$ 濃度の低い赭が大量に分泌せら゙れるようになつたという報告

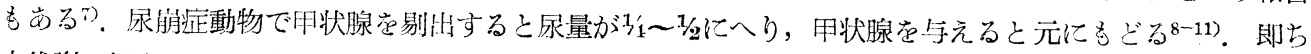
水代謝の観点で，甲状腺は脳下垂体後葉と拮抗的であるといえる．さらに甲状腺と後葉との関係について， Courrier ${ }^{12)}$ はウサギの静脈内に注射した labeled thyroxine が特に後葉に蓄積することを，Jentzer ${ }^{13)}$ はウサ ギの静脈内に注射したI $\mathrm{I}^{131}$ が同様後葉に䈉積することを報告した。，ての事実は，甲状腺ホルモンが後葉の機 能に何等かの影響を与えるであろうこと省暗示している。 ここで著者は, 甲状腺機能の消長が後葉の ADH 量に及ばす影響を，組織化学的並びに生物学的に観察するとととした。

\section{実 験 方 法}

丰駼動物として，数年来同一系統間のみで交配繁殖せしめてきた体重 100 1 $150 \mathrm{~g}$ の雄シロネズミを用いた。 これらネズミはすべて同一環境で一定条件の下に飼育し，飼料としては，ふすま，小麦，青野菜及で魚粉芭 与えた，通常垁験に先立つて約18時間絶食せしめたが，水は自由に摂取せしめた。

組織学的検索 本実験は 5 月より10月にわたつて次の 5 群のネズミについて行つた。

(1) 甲状腺剔出 (13例) ether 麻酔下に甲状腺を剔出した．上皮小体は小鈎で甲状腺組織を附着せしもな い上うに充分注意しつ〉えぐり取り，気管側部に埋没した．4例は手術後第24日に，9例は手術後第30日に 屠殺，検索に供した，屠殺後，甲状腺剔出部位は連続切片を作つて腺組織の残存並びに再生の有無を検した。

（2）甲状腺偽剔出（8 例）上記と同様の手術的侵襲を与えたが，甲状腺の剔出を行わなかつたもので，剔 出群と同じく手術後第24日及び第30日目に屠殺, 検索に供した。

（3）甲状腺剂投与（７例）Thyradin (耍国臟器) を体重 $100 \mathrm{~g}$ 当り $0.05 \mathrm{cc}$ づつ(乾燥甲状腺 $10 \mathrm{mg}$ に相当) 1 日1 回，連続皮下注射，3例は12日後，4例は23日後に屠殺検索に供した.

（4）生理的食塩水注射 ( 3 例) Thyradin 注射群の対照として, 同容量の生理的食塩水を12日間及び 23日 間連続注射した。

(5) 無処置対照 ( 5 例)上玅 4 群と同一環境で，全く無処置のま〉飼育したものである.

動物は屠殺に当り, Chloroform で急速に麻酔し，直ちに開胸して，心内に生理的食塩水，つれでZenkerFormalin 液を注人固定した。乙の装作後直ちに頭蓋を開密視床下部及び脳下垂体部を頭莣底骨と共に小塊 として切り出し, 建に Zenker-Formalin 液にて固定した. Paraffin に包埋後, $5 \mu$ の厚さに切り, 視床下部 の視索上核及び傍脳空核部並びに下垂体後葉部について, Gomori の chrome-alum-hematoxylin-phloxine 染色, Heidenhein の iron-hematoxylin 染色及び hematoxylin-eosin 染色を行い, この部の ADH 量の消 長前びに組織学的変化を観察した。

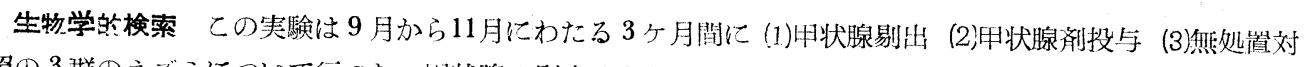
照の 3 群のネズミについて行つた。. 归状腺の剔出は上記と闰様で, 手術後28日目に屠殺, 実験に供した. 中

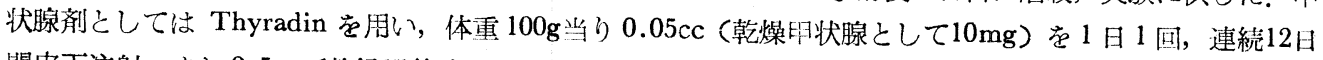
間皮下注射，また $0.5 \mathrm{cc}$ (乾燥甲状腺として $100 \mathrm{mg}$ ) を 1 日 1 回，連続28日間皮下注射して後，厤殺実験に 供した。 
睬下垂体 $\mathrm{ADH}$ 量の測定：ネズミの頸部を骨はさみで扼殺，頸部血管を切断して致死せしめ，直ちに頭蓋 を開き脳下垂体をとり出した，脳下垂体は乳鉢で清浄な海砂と共によくすりつぶし，0.25；醋酸を加えた生

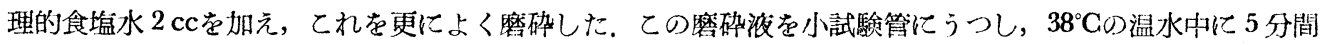

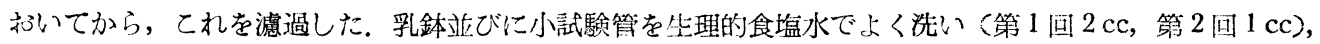

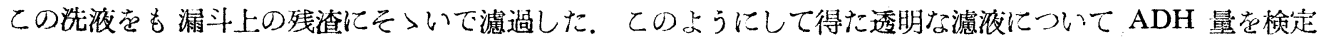

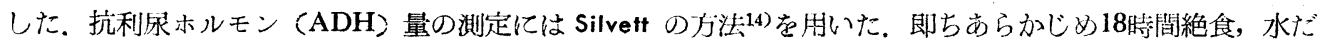
けを自时にとらしめて扔いたネズミに，体温にあたためた $0.2 \%$ 食塩水を体重 $100 \mathrm{~g}$ 当り $0.5 \mathrm{cc}$ 腹腔内に注射し た.このように処置したネズミを 3 凹で゙つ同じ代謝籠に人れ，その後 6 時間つ尿を集めて，その Cl 濃度を Volhard-Harvey の方法で測定した。このう法では，Vesopressinの投与量が体重 $100 \mathrm{~g}$ 当り $30 \mathrm{mU}$ 加 $80 \mathrm{mU}$ までの範井内にあれば，投与量と尿中 Cl 濃度との関係が面線になる。乙の検量曲線はネブミの種族及び実 験条件によつて多少変動する。それゆえ同群のネズミを朋い，試験の約 2 週間前に標準 Vasopressin 液によ る反応を試験し, 試験に際しては対照群をもうけ30又は $50 \mathrm{mU} の$ Vasopressin を注射, さらに試験の約 2 週 間後に再び標準液による反応をみるととにした。そその結果同じ群のネズミは，乙れら 3 回の測定でほづ一定 した值が得られることを確かめた。 な打ての実験に用いた Vasopressin 標準液は大日本藏器研究所に扑て 調製せられたものである。

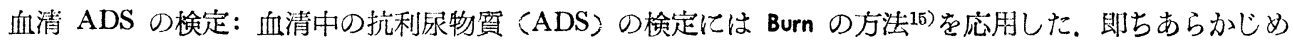
18時間絶食，水だけを自由に捸取せしめたシロネズミを用い，体重の $5 \%$ 量の温水を経口投与，直ちに血清 を体重 $100 \mathrm{~g}$ 当り $0.5 \mathrm{cc}$ 腹腔内に注射した。 その後の排出された㽷量を時間的に計測し，注射後 90 分間に排出 された尿量の負荷水量に対する百分比をもつて, 被検血清の抗利尿作用を比較することつした. 血清は, 頚 部切断によつて血液を採取し, 直ちに遠心分離したもので, 採取後可及的速汃に使用に供した。

\section{[I] 組織学的所見}

\section{実 験 成綪}

1) 無処置対照群，生理的食塩水注射群並びに申状腺偽剔出群

これら 3 群は殆ど闰一所兒を示すので一括記述する。下垂体後葉の Gomori 物質は，後柋の辺縁部及び 中葉に接する部分では微細顆粒乃至中等大顆粒として濃愿に，後葉の中央部ではや〉稀濩に分布していた。

第 1 図

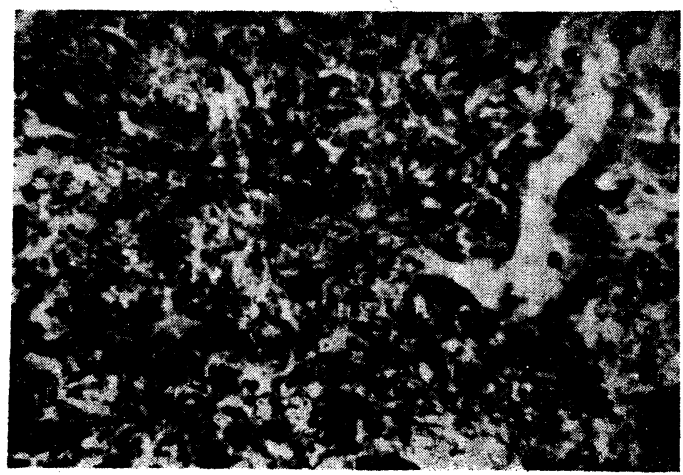

下垂体茎部に連なる部分でも分布が若干稀 薄であつた。いわゆる Herring 体と称せら れる様な比較的大きいものでは，均一に染色 せずその中央部でや〉稀薄になつているもの があつた. 一般に Gomori 物澌の濃度はそれ 程濃密ではなく，間質の構造を覆いかくすに は至らなかつた。即ち Gomori 物質を透して 間質組織或は Pituicyte の輪廍を透見し得た。 Pituicyte の核は, 円形乃至棈忺形で, chromatin 網は微細，核膜は明瞭であつた。原形 筫は，核をとり囲む狭い空隍様の嫌色素性， 琹柾な構造を示すものと， Gomori 物資が核 に密接して分们するためてれを認め得ないる

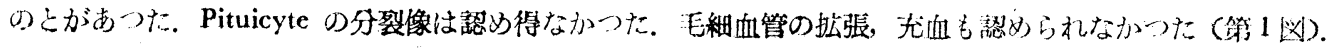

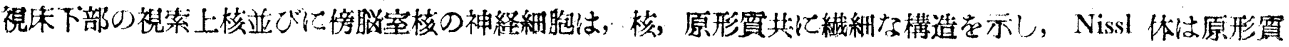
内に汒く分布していた，原形望が Gomori 物筫をふくむため青色調を示すものもあつた，神経細胞間及び 睬底面に接する神経線維間に滴状或は連珠状に連なる Gomori 物資をみとめ待た。

2) 甲状腺剔出群 
第2 2 図

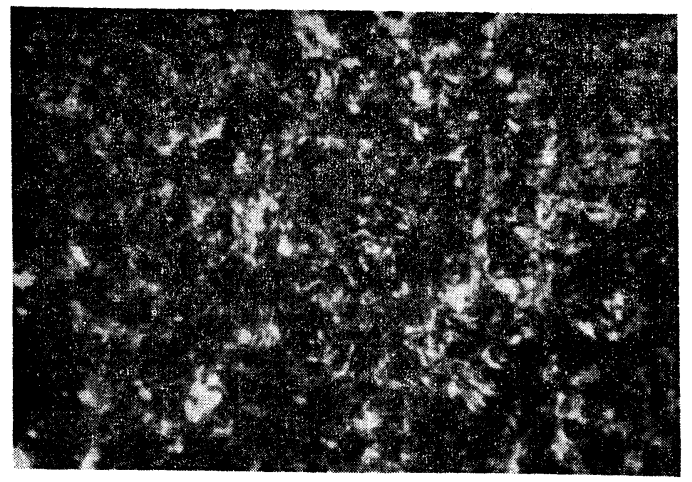

脳下垂体後葉の Gomori 物質は微細顆精 状のものより小乃至中等大顆精をなすものま で豊富に分布し，その量は前項記述の無処犆 対照群或は甲状腺偽剔出群より多汃つた。特 に中等大顆粒をなす Gomori 物筫が䇺富で， 中葉に接する部分並びに後葉周辺部はもとよ り中央部にも謴厚に分布する。間質治ての密 在する Gomori 物質に招〉われて透光し 難 く, 一部の例では Pituicyte すら充分にその

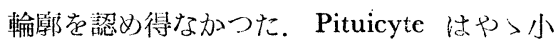
型のものが多く，核も概して小さく，川形或 は棈门形をなし，chromatin 網は縅紼であつ

た。原形質は密在する Gomori 物質のため認得ないものが多かつた。間質組織は瀻細であつた。 Pituicyte の分裂像，毛細血管の拡張，充血住共認めなかつた(第 2 図).

視床下部の視索上核，傍脳察核の神経細胞の大きさは概ね正常であるが，中にはや〉小型のうのもあつた， Nissl 体の分布はぼ゙正常, 核が原形質に比へてや〉大きいものがあつた。 Gomori 物質が神経細胞間には 滴状に，原形質内には桷慢性にみとめられ，その量法正常対照と殆ど変りなかつた。

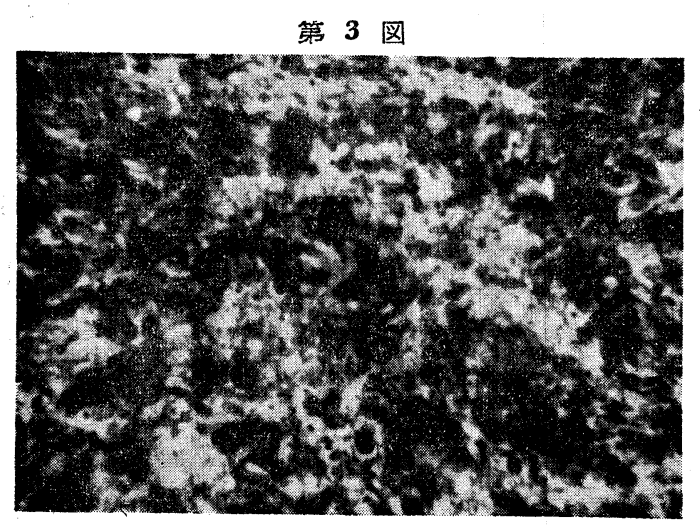

3) 甲状腺剂注射群

下垂体後葉汇捛いて Gomori 物筫が若干 減少していた. その分布は不均一となつて打 り，此校的濃厚な部分と稀隼な部分とがあつ て，稀漼部分では間質組織を明瞭沉認め得た。 Pituicyte は，核は繊細な構造を示し，原形 質が Gomori 物質を含まず，その鬆柾な構 造を認得るものが少くなかつた，Pituicyte

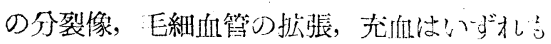
認奵られなからた第 3 汹》。

視索上核, 傍脳室核の神経細狍では，原形 質が繊細で，Gomori 物質を人れて青色調を

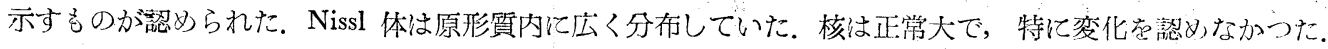
神経紐胞間立びに脳底部神経線維内に若干の Gomori 物質を点状或は絮状に認めた。

な抢，甲状腺剤12日間投与例と 23 日間投与例との間に特別な差異をみなかつた。

以上を総括するに，脳下垂休後莱の Gomori 物質は，甲状腺剔出動物の方が対照動物に打けるよりも辢 富に存在して打り，甲状腺剂投与動物では対照動物に比へて若干少なふつた。 Pituicyte 並びに间筫組織に

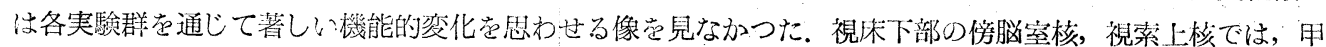
状腺剔出動物飞扔いて，細胞体が小さく核が比較的大きい神経細胞を若干認めた以外，特異の所筧を得なか วた.

\section{[II] 生物学的測定結果}

\section{1) 脳下垂体 $\mathrm{ADH}$ 量}

正常雄シロネズミ11例での脳下垂体 $\mathrm{ADH}$ 合量は710 380mUで，平均507mUであつた，体重 $100 \mathrm{~g}$ 当り 飞計算すると460３00mU平均362士 18mU (S.E:)であつた。 甲状腺剔出28日後のネバミ10例では720〜425 $\mathrm{mU}$ 平均 $580 \mathrm{mU}$ で，体重 $100 \mathrm{~g}$ 当りの值は $464 \sim 321 \mathrm{mU}$ ，平均 $390 \pm 13 \mathrm{mU}$ であうた，即ち闸状腺剔出ネズミの

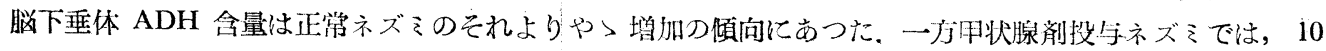




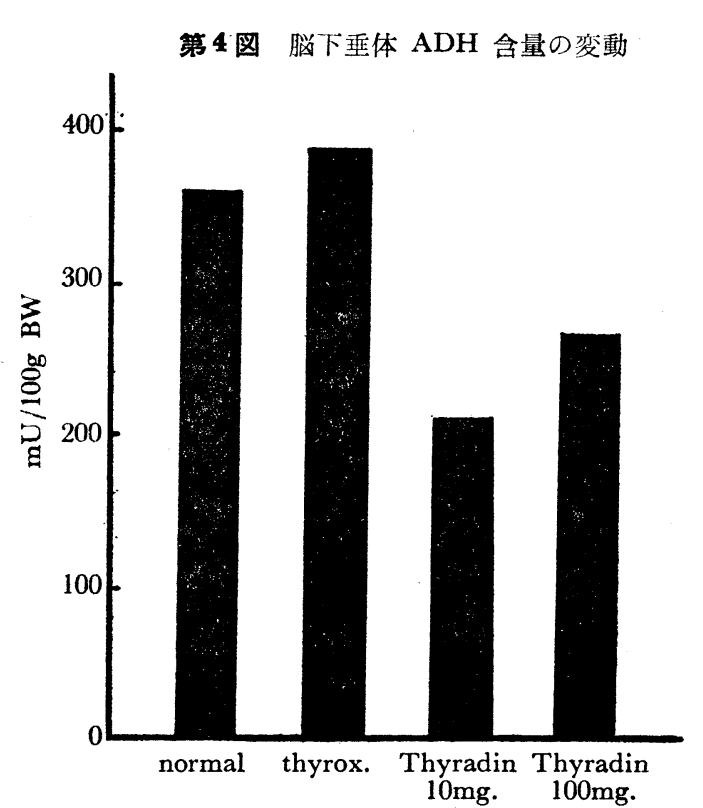

$\begin{array}{ccccc}\begin{array}{c}\text { No. of } \\ \text { animals }\end{array} & 11 & 10 & 8 & 5 \\ \text { S.E. } & \pm 18 & \pm 13 & \pm 15 & \pm 15\end{array}$

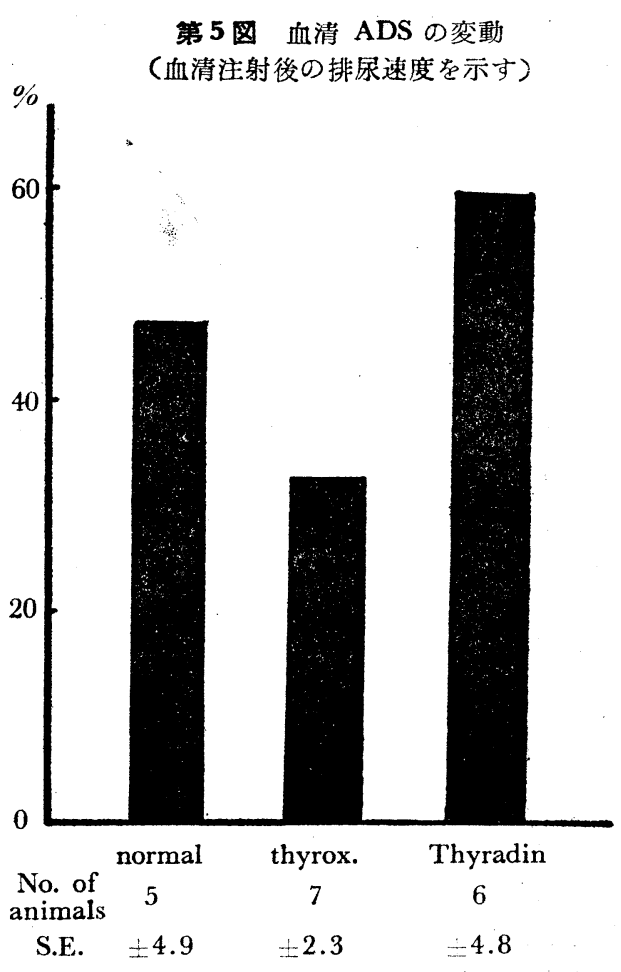

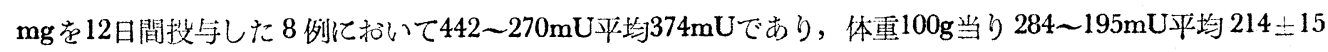

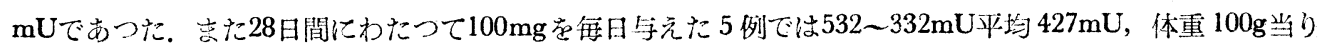
310 240mU平均 $267 \pm 15 \mathrm{mU}$ となつた. 即ち甲状腺郕の段与によつて脳下垂体の $\mathrm{ADH}$ 量が明汃な減少を示 した，以上の成績をまとめて第 4 図に示す。.

2) 血清 $\mathrm{ADS}$

正常対照ネズミの血清注射後 90 分に㧍ける排尿率 $\left(\frac{90 \text { 分排尿量 }}{\text { 負荷水量 }} \times 100\right)$ は，5例平均 47.4 工 $4.9 \%$ \%゙あ

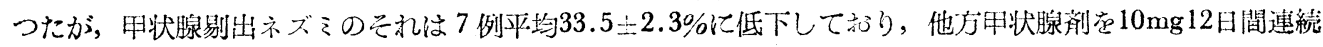
皮下注射したネズミの血清を注射した場合には 6 例平均 $61.0 \pm 4.8 \%$ であつた (第 5 図). 即ち正常血清に比 べて甲状腺剔出ネズミの血清は抗利尿作用が強く, 甲状腺䠼投与ネズミの血清はこの作用が弱いという結果 になつた。

な扢ての実験で各群のネズミ 5 匹づ〉について永量の測定を試みたが，甲状腺剔出群の12日聞の尿量は正

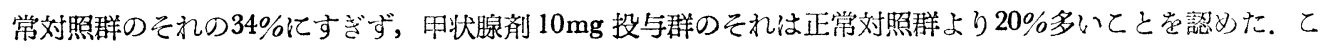
の尿量の増減は上記血清 $\mathrm{ADS}$ の変動と軌を一にするものである.

考按

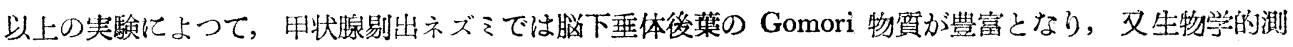

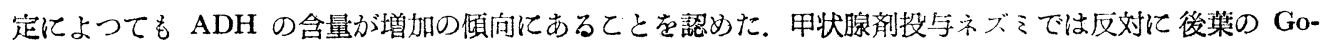
mori 物質が減少し, $\mathrm{ADH}$ 含量が低下していた。即ち甲状腺ホルモンは後栄の $\mathrm{ADH}$ 量它減少せしぬる. このホルモンが火如すれば後葉の $\mathrm{ADH}$ 量が增加すると考えられる。.

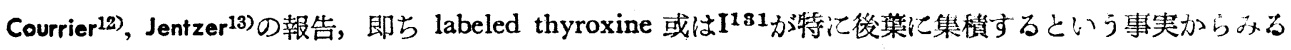
と, 甲状腺ホルモンが直接後葉に何等かの影響を与えるかも知れない.もし甲状腺ホルモンが後葉に作用し 
て ADH の分泌を促すととによつて後葉の ADH 含量が減少すると考えると，甲状腺の投与によつて利尿

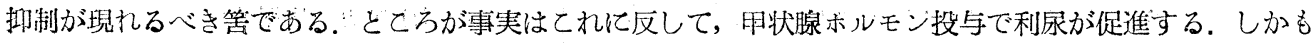
本実験で琶めた如く，甲状腺剤投与後血清 ADS の減少があるから，甲状腺ホルモンは ADH の産生を減

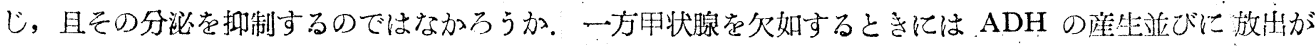
增し，血清 $\mathrm{ADH}$ の増加を来し，乙れが尿量減少の原因の一つになるかと思われる。

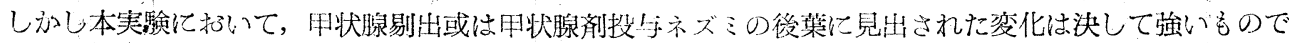

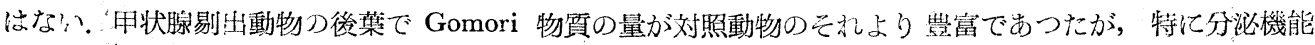

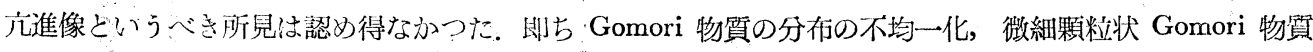
の減少, Gomori 物躓つ血管或仗 Pituicyte 周边への集積, その他組織学的変化をみなかつた. 又生物学的 に測定した $\mathrm{ADH}$ 量も忖状腺剔出ネズミで僅が增加の傾向を示したに過ぎない，他方甲状腺郕投与動物 でも，後葉の Gomori 物質が若干減少した以外特記すべき所見がなく，視床下部核の神経䋖胞にも殆ど変化 がなかつた。

Hare 等 ${ }^{16)}$ によると，実験的尿崩症のイヌに用状腺剤を長期投与した場合，腎細尿管の ADH に対する感 受性が低下し, その閾值は $0.5 \mathrm{mU}$ 加ら $20 \mathrm{mU}$ まで昇したという。従つて, 加りに後葉加らの $\mathrm{ADH}$ 分泌の

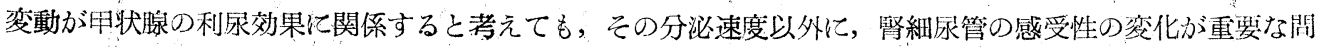
題となる.ささら 利尿效果は後枼以外の内分泌系を介して現れるか子知れないたたとえば White 及び Heinbecker ${ }^{17}, 18$ は下垂 体前葉の利尿因子が甲状腺ホルモンの存在の下で効果を発現すると考光，Gaunt 等19) は甲状腺ホルモンが副 筒皮質機能をたかめるととによつて利㽷を促進する可能性を指摘した。更に，甲状腺の利尿機序を一般代謝

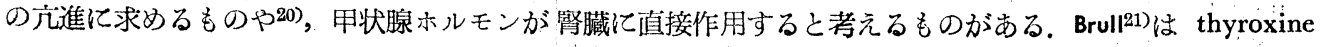
を投与したイヌの婜が投与しないイ邓の婜よりも多量の水を排出するてとを知り，thyroxine の利尿効果は 腎付対する直接作用であるとし，Eiler22)は thyroxine が細尿管に扣ける phosphorylation を昂めることに よつて分必を促進すると考えた，乙れらの文献加々ると，甲状腺の利尿効果は後葉 ADH の分泌の変化

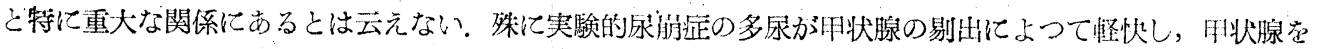

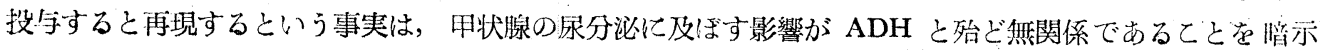
していると云つてょからう。

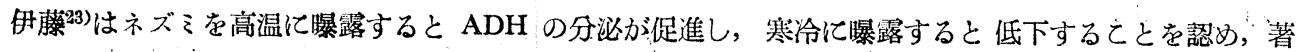

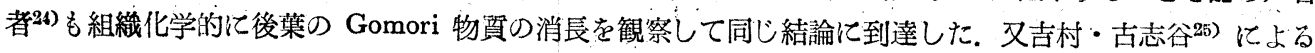

と, 冬季の血清 ADS は夏季或は高温馴化後のそれよりも低いという．冬季甲状腺の機能が元進し，夏季娍 退するととは周知の事実である. 本実験成績から見ると, 甲状腺機能元進時後葉の ADH 分泌が娍ずるの であるから，てれは冬季に扔ける $\mathrm{ADH}$ 分泌娍と一致し，反対に甲状腺機能低下時に招けるADH 分泌の 艺倠は夏季の $\mathrm{ADH}$ 分泌芯倠に一致する. ADH 分泌の季節的変動が必ずしも甲状腺機能の变化のみによる とは云えないが，その消長が同一方向にあるてとは興味あるととである.

\section{結 論}

1.甲状腚剔出によりシロネズミの脳下垂体の ADH は軽度の増加の傾向を示し, 血清 ADS にき若干 の增加を然めた。

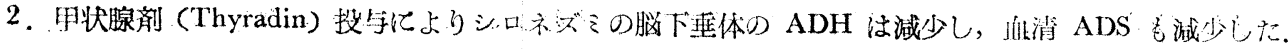

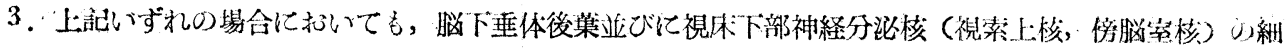
胞には，組織学的にみて特に挙ぐん゙き変化を示さな加つた。

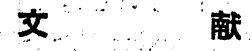

1) Bruhn, J.M.: Amer. J. Physiol. 135: 572, $1942 . \quad$. 2) Hare, K.: Res. Publ. Assoc. Nerv. \& Ment. 
Dis. 20: 416, $1940 . \quad$ 3) White, H.L., P. Heinbpgker, \& E,C. Robinson : Proc. Soc. Exper. Biol. \& Med. 38: 439, 1938. $\quad$ 4) Fisher, C.,W.R. Ingram, W.K. Hare, \& S.W. Ranson: Anat. Rec. 63: 29, $1935 . \quad 5)$ Clark, G.: Quart. Bull. Northwest. Univ. Med. School. 14: 94, 1940. ‥ 6) Liv, S.H.: Arch. Int. Med. 40: 73, 1927. $\quad$ 7) Gcunt, R.: Feder. Proc. 3: 12, $1944 . \quad$ 8) Fisher, C. \& W.R. Ingram: Arch. Int. Med. 58: 117, 1936. 9) Manchester, R.C.: Proc. Soc. Exper. Biol. \& Med. 29: 717, 1932. 10) Barnes, J.O., J.F. Regan, \& J.G. Bueno: Amer. J. Physiol. 105: 559, 1933. "11) Mahoney, W. \& D. Sheehan: ibid. 112: 250, 1935. 12) Courrier, R.: Ciba Foundation Colloquia on Endocrinology 4 : 311, 1952. 13 ) Jentzer, A.: Acta Endocrinol. 12: 264, 1953. $\quad 14)$ Silvett, H.: Proc. Soc. Exper. Biol. \& Med. 45: 599, 1940. 15) Burn, I.H.: Quat. J. Pharm. \& Pharmacol. 4: 517, 1931. 16) Hare, K., D. M. Phillips, J., Bradskaw, G. Chamber. \& R.S. Hare: Amer. J. Physiol 141: 187, 1944. 17) White, H.L. \& P. Heinbecker: ibid. 118: 276, 1937. 18$)$ Heinbecker, P. \& H.L. White: Ann. Surg. 110: 1037, 1939. 19) Gaunt, R., J. H. Birnie, \& W.J. Eversole: Physiol. Rev. 29: 281, 1949. 20) Bruhn, J.M.: Amer. J. Physiol. 135: 572, 1942. $\quad$ 21) Brull, L.: Quat. J. Exper, Physiol. 30: 195, - 22) Eiler, J.J., T.L. Althansen \& M. Stockholm: Amer. J. Physiol. 140: 699, 1944. 23) Itoh, S.: Jap. J. Physiol., 4: 185, 1954, 24) Ueno, T.: Nagoya J. Med. Sci. in press 25) 吉村寿人，古志谷淳三; 寒気生理第一同協議会報告, 4 頁, 1956 . 